Vol 1. No. 4, Oktober 2021 P-ISSN : 2774-8030, e-ISSN : 2774-8030

\title{
PENGARUH MODEL PEMBELAJARAN DAN KEMANDIRIAN BELAJAR TERHADAP KEMAMPUAN BERPIKIR KRITIS KIMIA SISWA KELAS X SMK DI KABUPATEN BOGOR
}

\author{
EVY CITRA AYU NEGARI \\ SMK Negeri 1 Gunungputri \\ e-mail: evycitraayunegari@gmail.com
}

\begin{abstract}
ABSTRAK
Penelitian ini bertujuan untuk menganalisis dan menguji kebenaran hipotesis mengenai pengaruh Model Pembelajaran dan Kemadirian Belajar terhadap Kemampuan Berpikir Kritis Kimia (Eksperimen pada SMK Negeri di Kabupaten Bogor). Penelitian ini merupakan penelitian eksperimen pada siswa SMK Negeri Kabupaten Bogor tahun pelajaran 2018/2019 semester 2. Pengumpulan data dilakukan dengan penyebaran angket/kuesioner tentang kemandirian belajar langsung kepada sampel dan pengerjaan soal kemampuan berpikir kritis. Validitas instumen penelitian dilakukan dengan rumus Product Moment Pearson Correlation. Reliabilitas instrumen dengan menggunakan rumus Alpha Cronbach. Analisis deskripsi meliputi mean, median, standar deviasi dan pengujian persyaratan analisis yang meliputi uji normalitas dan uji homogenitas sebelum melakukan analisis data terlebih dahulu. Teknik analisis data yang dipakai untuk menguji hipotesis adalah dengan teknik analisis ANAVA Dua Arah. Hasil penelitian menunjukkan: 1) Terdapat pengaruh yang signifikan model pembelajaran terhadap kemampuan berpikir kritis kimia siswa SMK Negeri di Kabupaten Bogor. Hal ini dibuktikan dengan sig. $=\mathbf{0 . 0 0 0}<\mathbf{0 . 0 0 5}$ dan $\mathbf{F}_{\text {hitung }}=\mathbf{3 1 . 6 9 3}$. 2) Terdapat pengaruh yang signifikan kemandirian belajar terhadap kemampuan berpikir kritis kimia siswa SMK Negeri di Kabupaten Bogor. Hal ini dibuktikan dengan sig. $=\mathbf{0 . 0 0 1}<\mathbf{0 . 0 0 5}$ dan $\mathbf{F}_{\text {hitung }}=$ 11.696. 3) Terdapat pengaruh interaktif yang signifikan model pembelajaran dan kemandirian belajar terhadap kemampuan berpikir kritis kimia siswa SMK Negeri di Kabupaten Bogor. Hal ini dibuktikan dengan sig. $=\mathbf{0 . 0 0 3}<\mathbf{0 . 0 0 5}$ dan $\mathbf{F}_{\text {hitung }}=\mathbf{9 . 3 1 2}$.

Kata Kunci: Model Pembelajaran PBL-STEM, Kemandirian Belajar, Kemampuan Berpikir Kritis SMK
\end{abstract}

\section{PENDAHULUAN}

Tantangan era revolusi industri 4.0 adalah bahwa semua bidang kehidupan dihadapkan fenomena penggantian sistem lama menjadi sistem baru yang berbasis teknologi. Tak terkecuali di bidang pendidikan. Pendidikan juga mempunyai dampak dari perkembangan zaman saat ini melalui model, media pembelajaran dan lainnya. Guru wajib menyediakan sebuah metode pembelajaran yang menciptakan kesempatan pada peserta didik untuk menghubungkan antara pengetahuan dan keterampilan sehingga menjadi terbiasa bagi peserta didik. Pendekatan pembelajaran yang dapat menjawab tantangan revolusi industri 4.0 adalah STEM. Singkatan STEM adalah Science, Technology, Engineering dan Mathematics.

Gagasan STEM education yang diutarakan Sanders (2009:21) mencakup pendekatan pembelajaran antara dua atau lebih bidang STEM yaitu konsep sains, teknologi, teknik dan matematika. Penerapan STEM dapat didukung oleh berbagai metode pembelajaran yang digunakan untuk mendukung penerapannya (Permanasari, 2016: 29). Pendekatan pembelajaran STEM dengan menintegrasikan keempat komponennya menuntut peserta didik menjadi innovator, pemecah masalah dan penemu yang percaya diri, sadar teknologi serta mampu berpikir logis.

Salah satu model pembelajaran yang menjadi rujukan pelaksanaan kurikulum 13 adalah model Problem Base Learning (PBL). Menurut Tan (2017: 217) PBL menyajikan masalah kontektual sehingga merangsang peserta didik untuk bekerja dalam tim untuk memecahkan masalah dunia nyata (real world). Fokus PBL adalah siswa. PBL mengarahkan siswa menjadi pembelajar yang mandiri dan terlibat langsung secara aktif dalam pembelajaran tim. (Riyanto, 2010: 308). Sedangkan Lefudin (2017: 234) memaparkan bahwa dalam pelaksanaan 
pembelajaran berbasis masalah menggunakan masalah dunia nyata sebagai suatu konteks bagi peserta didik untuk belajar tentang cara berpikir kritis dan keterampilan pemecahan masalah serta untuk memperoleh pengetahuan dan konsep yang essensial dari materi pelajaran. Sri Fatmawati juga menambahkan bahwa STEM bertujuan untuk mengembangkan pengetahuan, pemahaman konseptual, kemampuan berpikir kritis, menyiapkan peserta didik untuk berperan dalam sejumlah lapangan kerja yang terkait dengan STEM, mengajak peserta didik untuk berkonstribusi dalam perkembangan ekonomi, pemahaman terhadap diri sendiri (Fatmawati, 2015: 53). Artinya model pembelajaran PBL-STEM dapat meningkatkan pengetahuan, pemahaman konseptual, kemampuan berpikir kritis dan menyiapkan peserta didik untuk berperan dalam sejumlah lapangan kerja.

Selain pemilihan disain pembelajaran, faktor kemandirian peserta didik juga mempengaruhi kualitas belajarnya, Oemar Hamalik memaparkan bahwa pelaksanaan proses pembelajaran ditititkberatkan pada keaktifan siswa belajar dan keaktifan guru menciptakan lingkungan belajar yang serasi dan menantang (Hamalik, 1999: 138). Menurut Enung Fatimah (2010:143) kemandirian adalah "keadaan seseorang yang mampu mengambil keputusan dan inisiatif untuk mengatasi masalah yang dihadapi, memiliki kepercayaan diri dalam mengerjakan tugas-tugasnya dan bertanggung jawab terhadap apa yang dilakukannya". Kemandirian belajar merupakan aktifitas belajar yang didorong oleh kemauan sendiri dan tanggung jawab sendiri oleh pembelajar. (Tirtarahardja dan La Sulo, 2005: 50).

Sedangkan Bandura (Uno, 2008:217) mendefinisikan kemandirian belajar sebagai kemampuan untuk mengontrol prilaku mereka sendiri dan juga bekerja keras. Moore mengungkapkan dikutip dalam Rusman (2014:366), kemandirian belajar ditandai dengan ciri-ciri khusus 1) peserta didik sudah mengetahui dengan pasti apa yang ingin dicapai dalam kegiatan belajarnya; 2) peserta didik sudah dapat memilih bahan-bahan pelajaran; 3) peserta didik sudah dapat memberikan penilaian level kemampuan yang diperlukan untuk menyelesaikan suatu pekerjaan.

Berdasarkan penjelasan di atas model pembelajaran PBL-STEM dengan kemandirian yang tinggi dapat dapat meningkatkan kemampuan peserta didik dalam berpikir kritis. Richard Paul mengatakan berpikir kritis merupakan proses intelektual secara disiplin yang aktif dan terampil dalam mengkonsep, menerapkan, menganalisis, mensintesis dan/atau mengevaluasi informasi yang dikumpulkan dari, atau dihasilkan oleh observasi, pengalaman, refleksi, penalaran. (Fisher, 2011: 5). Kemudian Stella Cottrell (2017:1), berkata berpikir kritis adalah kegiatan kognitif, yang terkait dengan penggunaan pikiran. Belajar berpikir analitis dan evaluatif secara kritis berarti menggunakan proses mental seperti perhatian, kategorisasi, pemilihan dan penilaian. Kokom (2010: 226) menambahkan bahwa secara teknis, kemampuan berpikir dalam bahasa Bloom diartikan sebagai kemampuan intelektual yaitu kemampuan menganalisi, mensintetis dan mengevaluasi. Sehingga dengan bahasa lain kemampuan ini dapat dikatakan sebagai kemampuan berpikir kritis.

Bertitik tolak dari uraian di atas, dalam upaya meningkatkan kemampuan berpikir kritis peserta didik, sangat menarik diteliti pengaruh penggunaan model pembelajaran PBL-STEM ditinjau dari kemandirian belajar. Masalah penelitian ini adalah 1) pembelajaran di sekolah masih berpusat pada guru sehingga tidak sesuai dengan Kurikulum 13 yang menerapkan pembelajaran aktif; 2) siswa tidak terbiasa mengerjakan soal-soal dengan tingkat kemampuan berpikir kritis tinggi dikarenakan masih kurangnya soal-soal dengan tingkat kemampuan berpikir kritis tinggi yang tersedia di buku pelajaran sekolah; 3) rendahnya kemampuan berpikir kritis siswa dikarenakan terbatasnya kesempatan siswa untuk aktif dalam setiap kegiatan pembelajaran sehingga siswa tidak bisa mengkonstruksi pengetahuan mereka sendiri; 4) masih terbatasnya pengetahuan guru tentang variasi model pembelajaran untuk mendorong siswa belajar aktif; 5) guru kurang mengetahui secara aplikasi di kelas bahwa model pembelajaran PBL dengan pendekatan STEM dapat meningkatkan kemampuan berpikir kritis siswa; 6) siswa terbiasa mengandalkan penjelasan guru di papan tulis atau disuruh oleh guru dan selalu 
cenderung menunggu jawaban guru kemudian mencatatnya; 7) kemandirian belajar siswa belum diperhitungkan kontribusinya dalam meningkatkan keberhasilan suatu pembelajaran.

Penelitian ini bertujuan untuk menganalisis dan menguji kebenaran hipotesis mengenai pengaruh Model Pembelajaran dan Kemandirian Belajar terhadap Kemampuan Berpikir Kritis Kimia.

Kegunaan penelitian ini adalah untuk dapat mengembangkan kemampuan berpikir kritis kimia siswa, dan juga diharapkan guru mendapatkan wawasan baru dalam pembelajaran dengan model Problem Base Learning (PBL)-STEM untuk meningkatkan kemampuan berpikir kritis kimia siswa, sehingga memberikan sumbangan yang baik dalam rangka perbaikan proses pembelajaran, guna meningkatkan kualitas pembelajaran kimia

\section{METODE PENELITIAN}

Metode penelitian yang digunakan dalam penelitian ini adalah eksperimen. Ada tiga variabel yang digunakan dalam penelitian ini adalah 1) variabel bebas 1, dalam hal ini merupakan variabel treatmen $(A)$ yaitu model pembelajaran PBL-STEM $\left(A_{l}\right)$ dan model pembelajaran konvensional $\left(A_{2}\right) ; 2$ ) variabel bebas 2 , dalam hal ini sebagai variabel atribut $(B)$ yaitu kemandirian belajar, dibedakan atas kemandirian belajar tinggi $\left(B_{l}\right)$ dan kemandirian belajar rendah $\left(B_{2}\right)$; dan variabel terikat, dalam hal ini sebagai variabel kriterium $(Y)$ yaitu kemampuan berpikir kritis berdasarkan kemampuan yang telah dirancang. Untuk diain penelitian dibuat dalam sebuah tabel, sebagai berikut:

Tabel 1. Disain Penelitian

\begin{tabular}{cccc}
\hline \multirow{2}{*}{$\begin{array}{c}\text { Kemandirian } \\
\text { Belajar }\end{array}$} & \multicolumn{2}{c}{ Model Pembelajaran } & \multirow{2}{*}{ Total } \\
\cline { 2 - 3 } Tinggi $\left(\mathrm{B}_{1}\right)$ & $\mathrm{A}_{1} \mathrm{~B}_{1}$ & $\mathrm{~A}_{2} \mathrm{~B}_{1}$ & $\Sigma \mathrm{B}_{1}$ \\
\hline Rendah $\left(\mathrm{B}_{2}\right)$ & $\mathrm{A}_{1} \mathrm{~B}_{2}$ & $\mathrm{~A}_{2} \mathrm{~B}_{2}$ & $\Sigma \mathrm{B}_{2}$ \\
\hline Total & $\Sigma \mathrm{A}_{1}$ & $\Sigma \mathrm{A}_{2}$ & $\Sigma$ Total \\
\hline
\end{tabular}

Populasi penelitian ini adalah siswa SMK kelas X di Kabupaten Bogor. Pada penelitian ini dipilih secara acak siswa kelas X SMK Negeri 1 Gunungputri sebanyak 468 siswa dan kelas X SMK Negeri 1 Cileungsi sebanyak 413 siswa. Penentuan sampel ini menggunakan teknik random sampling. Kemudian secara acak dari siswa kelas X SMK Negeri 1 Gunungputri dan kelas X SMK Negeri 1 Cileungsi dipilih dua kelas sebagai kelas eksperimen dan kelas kontrol. Pada penentuan sample subyek, dilakukan dengan cara terlebih dahulu mengadakan tes kemandirian belajar yang ada di kelas eksperimen dan kelas kontrol. Selanjutnya hasil tes pada masing-masing kelas diskor dan diurutkan dari nomor 1 sampai 17 (kelompok atas/kemandirian belajar tinggi) dan 55 sampai nomor 72 (kelompok bawah/kemandirian belajar rendah) pada masing-masing kelas eksperimen dan kelas kontrol diambil sebagai sampel subyek. Peserta didik lainnya tidak dijadikan sebagai sampel penelitian tetapi tetap disertakan dalam proses perlakuan agar suasana proses belajar alamiah dan tidak merasa sedang diteliti (natural learning observation).

\section{HASIL DAN PEMBAHASAN}

Hasil

Penelitian ini dilaksanakan di SMK Negeri 1 Gunungputri dan kelas X SMK Negeri 1 Cileungsi mulai bulan akhir Maret sampai dengan bulan Juli 2019 tahun pelajaran 2018/2019. Pembelajaran yang dilaksanakan yaitu model pembelajaran PBL-STEM pada kelompok eksperimen dan model pembelajaran konvensional pada kelompok kontrol. Materi yang diajarkan pada penelitian ini yaitu larutan asam basa.

Setelah mengelompokkan data berdasarkan kelas eksperimen yang diajarkan dengan model pembelajaran PBL-STEM pada kelompok eksperimen dan model pembelajaran konvensional pada kelompok kontrol dan mengelompokkan berdasarkan katagori kemandirian 
belajar, selanjutnya siswa diberikan soal untuk mengetahui kemampuan berpikir kritis kimia. Soal yang diberikan berbentuk essay sebanyak lima soal yang telah diujicobakan terlebih dahulu kemudian dilakukan uji validitas, uji reliabilitas, taraf kesukaran dan daya pembeda. Kemudian diambil soal yang sesuai kriteria.

Data hasil penelitian setiap kelas perlakuan dianalisis dengan teknik statistik deskriptif dan perhitungan data hasil penelitian dilakukan dengan menggunakan SPSS 20 di tabel 2. Sedangkan tabel 3 adalah konversi tabel output program SPSS ke format tabel disain penelitian.

\section{Tabel 2 Deskripsi statistik menurut rancangan penelitian dalam format output SPSS} Descriptive Statistics

Dependent Variable: Kemampuan Berpikir Kritis

\begin{tabular}{|cl|r|r|r|}
\hline $\begin{array}{c}\text { Model } \\
\text { Pembelajaran }\end{array}$ & \multicolumn{1}{c|}{ Kemandirian Belajar } & Mean & Std. Deviation & N \\
\hline \multirow{3}{*}{ A1 PBL-STEM } & B1 Kemandirian Belajar Tinggi & 8.971 & 2.8310 & 17 \\
& B2 Kemandirian Belajar Rendah & 5.353 & 1.8855 & 17 \\
& Total & 7.162 & 2.9968 & 34 \\
A2 Konvensional & B1 Kemandirian Belajar Tinggi & 4.118 & 1.3173 & 17 \\
& B2 Kemandirian Belajar Rendah & 3.912 & 2.8187 & 17 \\
& Total & 4.015 & 2.1689 & 34 \\
Total & B1 Kemandirian Belajar Tinggi & 6.544 & 3.2853 & 34 \\
& B2 Kemandirian Belajar Rendah & 4.632 & 2.4720 & 34 \\
& Total & 5.588 & 3.0419 & 68 \\
\hline
\end{tabular}

\section{Tabel 3 Deskripsi Statistik menurut Disain Penelitian}

\begin{tabular}{|c|c|c|c|}
\hline$\underbrace{\substack{\text { Model } \\
\text { Pelajar }}}_{\text {Kemandirian }}$ & $\begin{array}{c}\text { PBL_STEM } \\
\left(\mathbf{A}_{1}\right)\end{array}$ & $\begin{array}{c}\text { Konvensional } \\
\quad\left(\mathbf{A}_{2}\right)\end{array}$ & $\sum \mathbf{B}$ \\
\hline \multirow{3}{*}{ Tinggi $\left(\mathbf{B}_{1}\right)$} & $n=17$ & $n=17$ & $n=34$ \\
\hline & $\bar{X}=8.971$ & $\bar{X}=4.118$ & $\bar{X}=6.544$ \\
\hline & $s=2.831$ & $s=1.3173$ & $s=3.2853$ \\
\hline \multirow{3}{*}{ Rendah $\left(\mathbf{B}_{2}\right)$} & $n=17$ & $n=17$ & $n=34$ \\
\hline & $\bar{X}=5.353$ & $\bar{X}=3.912$ & $\bar{X}=4.632$ \\
\hline & $s=1.8855$ & $s=2.8187$ & $s=2.472$ \\
\hline \multirow{3}{*}{$\sum \mathbf{A}$} & $n=34$ & $n=34$ & $n=68$ \\
\hline & $\bar{X}=7.162$ & $\bar{X}=4.015$ & $\bar{X}=5.588$ \\
\hline & $s=2.9968$ & $s=2.1689$ & $s=3.0419$ \\
\hline
\end{tabular}

Berdasarkan tabel 2 menunjukkan bahwa untuk kelas eksperimen $\left(\mathrm{A}_{1}\right)$ mempunyai ratarata skor kemampuan berpikir kritis 7.162 jauh lebih besar dibandingkan kelas kontrol dengan skor rata-rata kemampuan berpikir kritis hanya sebesar 4.015. Secara deskriptif menunjukkan bahwa untuk kelas eksperimen dapat dinyatakan berhasil. Kemudian jika dilihat dari kemandirian belajar menunjukkan bahwa bagi siswa yang memiliki kemandirian belajar tinggi menunjukkan nilai yang lebih tinggi dibandingkan dengan kelompok siswa yang mempunyai kemandirian rendah. Kelompok siswa dengan kemandirian belajar tinggi mempunyai nilai ratarata kemampuan berpikir kritis sama dengan 6.544 sedangkan kelompok siswa yang yang mempunyai kemandirian rendah mempunyai rata-rata kemandirian belajarnya sama dengan 4.632, hal ini sesuai yang diharapkan.

Sebelum data dianalisis, dilakukan uji persyaratan analisis data yaitu uji normalitas dan uji homogenitas pada setiap kelompok data. Uji normalitas tersaji pada tabel 4. Berdasarkan tabel 4 terlihat bahwa sampel pada setiap kelompok data memiliki nilai Asymp. Sig > 0,05 maka dapat disimpulkan bahwa semua kelompok data kemampuan berpikir kritis kimia berdistribusi normal. 
Vol 1. No. 4, Oktober 2021 P-ISSN : 2774-8030, e-ISSN : 2774-8030

\begin{tabular}{|c|c|c|c|c|c|c|c|c|c|}
\hline & & $\begin{array}{l}\text { Model } \\
\text { PBL- } \\
\text { STEM }\end{array}$ & $\begin{array}{c}\text { Model } \\
\text { Konven } \\
\text { sional }\end{array}$ & $\begin{array}{l}\text { Keman } \\
\text { dirian } \\
\text { Belajar } \\
\text { Tinggi }\end{array}$ & $\begin{array}{l}\text { Keman } \\
\text { dirian } \\
\text { Belajar } \\
\text { Rendah }\end{array}$ & $\begin{array}{l}\text { Model PBL- } \\
\text { STEM dan } \\
\text { memiliki } \\
\text { Kemandirian } \\
\text { Belajar } \\
\text { Tinggi }\end{array}$ & $\begin{array}{l}\text { Model PBL- } \\
\text { STEM dan } \\
\text { memiliki } \\
\text { Kemandirian } \\
\text { Belajar } \\
\text { Rendah }\end{array}$ & $\begin{array}{c}\text { Model } \\
\text { Konvensional } \\
\text { dan } \\
\text { Kemandirian } \\
\text { Belajar } \\
\text { Tinggi } \\
\end{array}$ & $\begin{array}{c}\text { Model } \\
\text { Konvensional } \\
\text { dan } \\
\text { Kemandirian } \\
\text { Belajar } \\
\text { Rendah }\end{array}$ \\
\hline \multicolumn{2}{|l|}{$\mathrm{N}$} & 34 & 34 & 34 & 34 & 17 & 17 & 17 & 17 \\
\hline \multirow{2}{*}{$\begin{array}{l}\text { Normal } \\
\text { Parameters }{ }^{\mathrm{a}, \mathrm{b}}\end{array}$} & Mean & 7.162 & 4.015 & 6.544 & 4.632 & 8.971 & 5.353 & 4.118 & 3.912 \\
\hline & $\begin{array}{l}\text { Std. } \\
\text { Deviation }\end{array}$ & 2.9968 & 2.1689 & 3.2853 & 2.4720 & 2.8310 & 1.8855 & 1.3173 & 2.8187 \\
\hline \multirow{3}{*}{$\begin{array}{l}\text { Most Extreme } \\
\text { Differences }\end{array}$} & Absolute & .155 & .112 & .213 & .122 & 164 & .132 & .160 & .157 \\
\hline & Positive & .155 & .083 & .213 & .103 & .164 & .080 & .147 & .157 \\
\hline & Negative & -.070 & -.112 & -.064 & -.122 & -.099 & -.132 & -.160 & -.124 \\
\hline \multicolumn{2}{|c|}{ Kolmogorov-Smirnov Z } & .901 & .654 & 1.242 & .710 & .674 & .543 & .661 & .647 \\
\hline \multicolumn{2}{|c|}{ Asymp. Sig. (2-tailed) } & .391 & .786 & .092 & 695 & .753 & .930 & .775 & .797 \\
\hline
\end{tabular}

Pengujian homogenitas data kemampuan berpikir kritis pada kelas eksperimen dan kontrol memiliki kemandirian belajar dapat dilihat pada tabel 5 .

Tabel 5. Uji Homogenitas

Levene's Test of Equality of Error Variances ${ }^{\text {a }}$

Dependent Variable: Kemampuan Berpikir Kritis

\begin{tabular}{|c|c|c|c|}
\hline $\mathrm{F}$ & df1 & df2 & Sig. \\
\hline 4.184 & 3 & 64 & .009 \\
\hline
\end{tabular}

Tests the null hypothesis that the error variance of the dependent variable is equal across groups.

a. Design: Intercept $+\mathrm{A}+\mathrm{B}+\mathrm{A} * \mathrm{~B}$

Jika nilai sig (Levene's Test) $>0.05 \mathrm{H}_{0}$ diterima, $\mathrm{H}_{1}$ ditolak jika nilai nilai sig (Levene's Test $)<0.05$. Dari tabel 5, nilai Levene's Test of Equality of Error Variances di atas didapat data

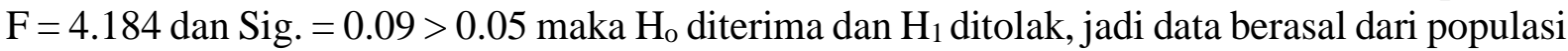
yang homogen.

Karena data berdistribusi normal dan homogen, maka dilakukan uji analisis yaitu dengan ANOVA dua arah dengan program SPSS 20 for Window, dapat dilihat di tabel 6.

\section{Tabel 6. Rangkuman Hasil ANOVA Dua Arah Data Kemampuan Berpikir Kritis Siswa Tests of Between-Subjects Effects}

Dependent Variable: Kemampuan Berpikir Kritis

\begin{tabular}{|l|r|r|r|r|r|}
\hline \multicolumn{1}{|c|}{ Source } & $\begin{array}{c}\text { Type III Sum of } \\
\text { Squares }\end{array}$ & df & Mean Square & \multicolumn{1}{c|}{ F } & \multicolumn{1}{c|}{ Sig. } \\
\hline Corrected Model & $279.971^{\mathrm{a}}$ & 0.9 & 93.324 & 17.567 & .000 \\
Intercept & 2123.529 & 1 & 2123.529 & 399.723 & .000 \\
$\mathrm{~A}$ & 168.368 & 1 & 168.368 & 31.693 & .000 \\
$\mathrm{~B}$ & 62.132 & 1 & 62.132 & 11.696 & .001 \\
$\mathrm{~A} * \mathrm{~B}$ & 49.471 & 1 & 49.471 & 9.312 & .003 \\
Error & 340.000 & 64 & 5.313 & & \\
Total & 2743.500 & 68 & & & \\
Corrected Total & 619.971 & 67 & & & \\
\hline
\end{tabular}

a. $\mathrm{R}$ Squared $=.452($ Adjusted $\mathrm{R}$ Squared $=.426)$

Berdasarkan hasil perhitungan pada tabel 6 dapat disimpulkan:

1) Pengujian Hipotesis Pertama: Terdapat pengaruh yang signifikan model pembelajaran terhadap kemampuan berpikir kritis kimia

Hipotesis ini untuk menguji ada atau tidaknya pengaruh yang signifikan model pembelajaran terhadap kemampuan berpikir kritis kimia. Berdasarkan pengujian dengan program SPSS 20 for Windows dari tabel Tests of Between-Subjects Effects di atas di dapat nilai sig. $=0.000<0.005$ dan $\mathrm{F}_{\text {hitung }}=31.693$, artinya $\mathrm{H}_{1}$ diterima dan $\mathrm{H}_{0}$ ditolak. Dengan demikian, 
dapat disimpulkan terdapat pengaruh yang signifikan model pembelajaran terhadap kemampuan berpikir kritis kimia.

2) Pengujian Hipotesis Kedua: Terdapat pengaruh yang signifikan kemandirian belajar terhadap kemampuan berpikir kritis kimia

Hipotesis ini untuk menguji ada atau tidaknya pengaruh yang signifikan kemandirian belajar terhadap kemampuan berpikir kritis kimia. Berdasarkan pengujian dengan program SPSS 20 for Windows dari tabel Tests of Between-Subjects Effects di atas didapat nilai sig. = $0.001<0.005$ dan $\mathrm{F}_{\text {hitung }}=11.696$, artinya $\mathrm{H}_{1}$ diterima dan $\mathrm{H}_{0}$ ditolak. Dengan demikian, dapat disimpulkan terdapat pengaruh yang signifikan kemandirian belajar terhadap kemampuan berpikir kritis kimia.

3) Pengujian Hipotesis Ketiga: Terdapat pengaruh interaktif yang signifikan model pembelajaran dan kemandirian belajar terhadap kemampuan berpikir kritis kimia

Hipotesis ini untuk menguji ada atau tidaknya pengaruh interaktif yang signifikan model pembelajaran dan kemandirian belajar terhadap kemampuan berpikir kritis kimia. Berdasarkan pengujian dengan program SPSS 20 for Windows dari tabel Tests of Between-Subjects Effects di atas didapat nilai sig. $=0.003<0.005$ dan $\mathrm{F}_{\text {hitung }}=9.312$, artinya $\mathrm{H}_{1}$ diterima dan $\mathrm{H}_{0}$ ditolak. Dengan demikian, dapat disimpulkan terdapat pengaruh interaktif yang signifikan model pembelajaran dan kemandirian belajar terhadap kemampuan berpikir kritis kimia.

Hasil uji hipotesis ketiga adalah pengaruh intraktif kedua variabel terikat terhadap variabel bebas maka dilakukan uji simple effect denngan menngunakan uji Tukey.

a. Pengujian Lanjut

Pengujian lanjut dilakukan untuk mengetahui pengaruh perbedaan masing-masing kelompok. Adapun uji lanjut yang digunkan yaitu uji Tukey. Pengujian uji Tukey biasanya digunakan jika analisis data dalam penelitian dilakukan dengan cara membandingkan data antara dua kelompok (Supardi, 2016:334).

Hasil dari uji Tukey pada taraf signifikansi $(\alpha)=0.05$ dengan menggunakan SPSS 20 for Windows dirangkum pada tabel berikut ini:

Tabel 7 Hasil ANOVA Uji Lanjut dengan Uji Tukey Multiple Comparisons

Dependent Variable: Kemampuan Berpikir Kritis Tukey HSD

\begin{tabular}{|cl|r|r|r|r|r|}
\hline \multirow{2}{*}{$\begin{array}{c}\text { (I) Post } \\
\text { Hoc }\end{array}$} & $\begin{array}{c}\text { (J) Post } \\
\text { Hoc }\end{array}$ & $\begin{array}{c}\text { Mean } \\
\text { Difference } \\
\text { (I-J) }\end{array}$ & $\begin{array}{c}\text { Std. } \\
\text { Error }\end{array}$ & Sig. & & \multicolumn{2}{|c|}{$\begin{array}{c}\text { S Confidence } \\
\text { Interval }\end{array}$} \\
\hline \multirow{2}{*}{ A1B1 } & A1B2 & $3.618^{*}$ & .7906 & .000 & 1.532 & 5.703 \\
& A2B1 & $4.853^{*}$ & .7906 & .000 & 2.768 & 6.938 \\
& A2B2 & $5.059^{*}$ & .7906 & .000 & 2.973 & 7.144 \\
& A1B1 & $-3.618^{*}$ & .7906 & .000 & -5.703 & -1.532 \\
A1B2 & A2B1 & 1.235 & .7906 & .407 & -.850 & 3.321 \\
& A2B2 & 1.441 & .7906 & .272 & -.644 & 3.527 \\
& A1B1 & $-4.853^{*}$ & .7906 & .000 & -6.938 & -2.768 \\
A2B1 & A1B2 & -1.235 & .7906 & .407 & -3.321 & .850 \\
& A2B2 & .206 & .7906 & .994 & -1.880 & 2.291 \\
A2B2 & A1B1 & $-5.059^{*}$ & .7906 & .000 & -7.144 & -2.973
\end{tabular}


Vol 1. No. 4, Oktober 2021 P-ISSN : 2774-8030, e-ISSN : 2774-8030

\begin{tabular}{|l|r|r|r|r|r|} 
A1B2 & -1.441 & .7906 & .272 & -3.527 & .644 \\
A2B1 & -.206 & .7906 & .994 & -2.291 & 1.880 \\
\hline
\end{tabular}

Based on observed means.

The error term is Mean Square(Error) $=5.313$.

*. The mean difference is significant at the 0.05 level.

Berdasarkan data hasil uji lanjut pada tabel Multiple Comparisons di atas diperoleh model interaksi sebagai berikut:

1) Kelompok $\mathrm{A}_{1} \mathrm{~B}_{1}$ dan $\mathrm{A}_{2} \mathrm{~B}_{1}$

Dari tabel 7 hasil ANOVA uji lanjut dengan uji Tukey (Multiple Comparisons) dapat dilihat Mean Difference pada kelompok $\mathrm{A}_{1} \mathrm{~B}_{1}$ dan $\mathrm{A}_{2} \mathrm{~B}_{1}$ adalah 4.853 berarti selisih antara kelompok $\mathrm{A}_{1} \mathrm{~B}_{1}$ dan $\mathrm{A}_{2} \mathrm{~B}_{1}$ sebesar 4.853. Nilai ini cukup besar dan dapat dibuktikan deangan signifikansi untuk $\alpha=0.05$ adalah sebesar 0.000. $(0.000<0.05)$.

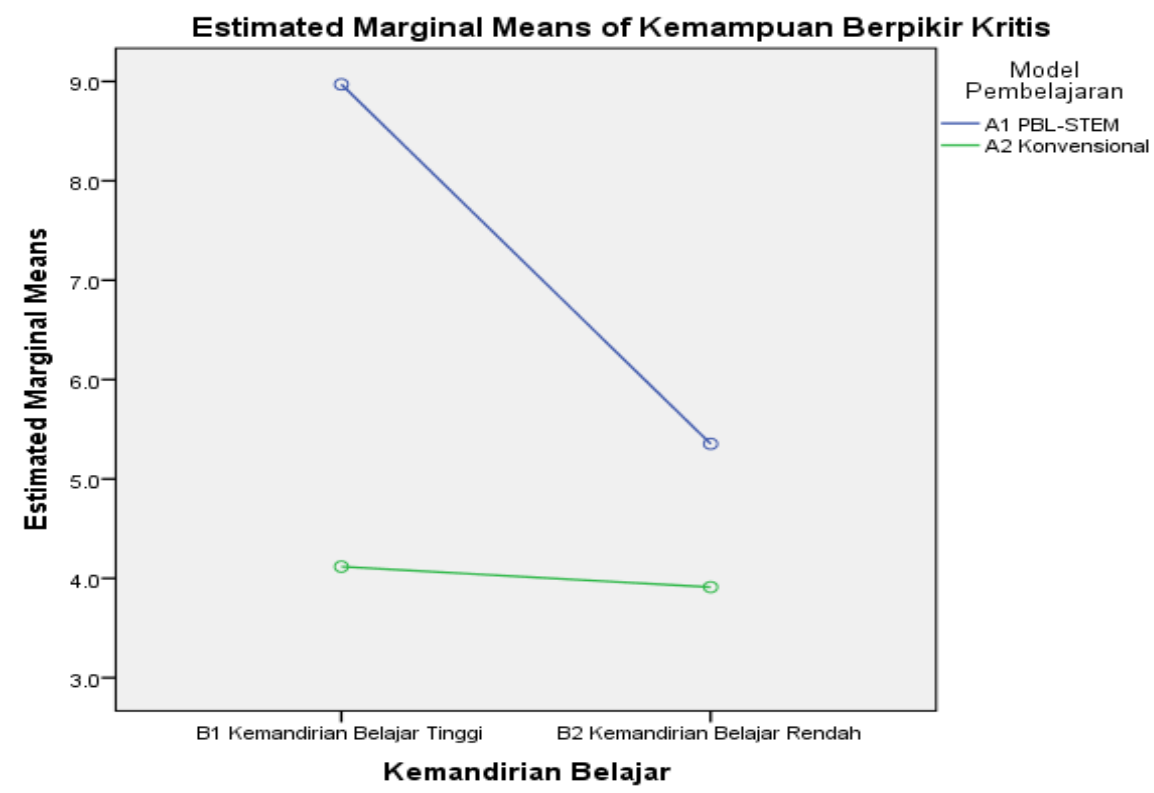

Gambar 1. Grafik perkiraan rerata margin kemampuan berpikir kritis (axis: kemandirian belajar)

Dari gambar 1, grafik di atas tampak bahwa kemampuan berpikir kritis model PBLSTEM lebih tinggi daripada model kovensional pada siswa dengan kemandirian belajar tinggi dan juga pada siswa dengan kemandirian belajar rendah.

Hal ini dapat diartikan bahwa antara kelompok $\mathrm{A}_{1} \mathrm{~B}_{1}$ dan $\mathrm{A}_{2} \mathrm{~B}_{1}$ berbeda secara signifikan. Atau menunjukkan $\mathrm{H}_{1}$ diterima dan $\mathrm{H}_{0}$ ditolak dengan kata lain terdapat perbedaan kemampuan berpikir kritis kimia yang diajarkan dengan model pembelajaran PBL-STEM dan konvensional, pada siswa berkemandirian tinggi.

2) Kelompok $\mathrm{A}_{1} \mathrm{~B}_{2}$ dan $\mathrm{A}_{2} \mathrm{~B}_{2}$

Dari tabel hasil ANOVA uji lanjut dengan uji Tukey (Multiple Comparisons) dapat dilihat Mean Difference pada kelompok $\mathrm{A}_{1} \mathrm{~B}_{2}$ dan $\mathrm{A}_{2} \mathrm{~B}_{2}$ adalah 1.441 berarti selisih antara kelompok $\mathrm{A}_{1} \mathrm{~B}_{2}$ dan $\mathrm{A}_{2} \mathrm{~B}_{2}$ sebesar 1.441. Nilai ini cukup kecil dan dapat dibuktikan deangan signifikansi untuk $\alpha=0.05$ adalah sebesar $0.272(0.272>0.05)$. 


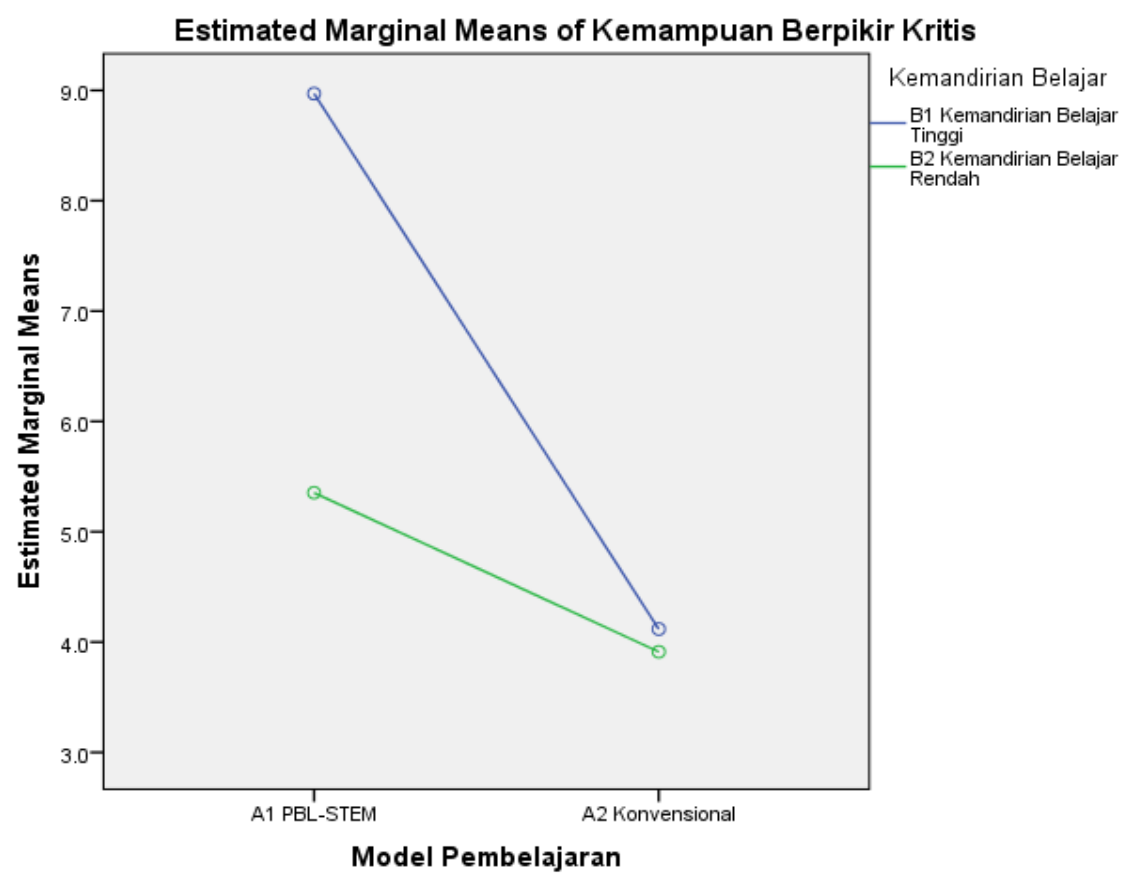

\section{Gambar 2. Grafik perkiraan rerata margin kemampuan berpikir kritis (axis: model} pembelajaran)

Dari gambar 2, grafik di atas juga tampak bahwa kemiringan garis kemandirian rendah tidak terlalu besar antara titik model pembelajaran konvensional dan titik model pembelajaran PBL-STEM.

Hal ini dapat diartikan bahwa antara kelompok $\mathrm{A}_{1} \mathrm{~B}_{2}$ dan $\mathrm{A}_{2} \mathrm{~B}_{2}$ tidak berbeda secara signifikan. Atau menunjukkan $\mathrm{H}_{0}$ diterima dan $\mathrm{H}_{1}$ ditolak dengan kata lain tidak ada perbedaan kemampuan berpikir kritis kimia yang diajarkan dengan model pembelajaran PBL-STEM dan konvensional, pada siswa berkemandirian rendah.

3) Kelompok $\mathrm{A}_{1} \mathrm{~B}_{1}$ dan $\mathrm{A}_{1} \mathrm{~B}_{2}$

Dari tabel hasil ANOVA uji lanjut dengan uji Tukey (Multiple Comparisons) dapat dilihat Mean Difference pada kelompok $\mathrm{A}_{1} \mathrm{~B}_{1}$ dan $\mathrm{A}_{1} \mathrm{~B}_{2}$ adalah 3.618 berarti selisih antara kelompok $\mathrm{A}_{1} \mathrm{~B}_{1}$ dan $\mathrm{A}_{1} \mathrm{~B}_{2}$ sebesar 3.618. Nilai ini cukup besar dan dapat dibuktikan deangan signifikansi untuk $\alpha=0.05$ adalah sebesar 0.000. $(0.000<0.05)$. Pada gambar 2 tampak kemiringan garis model pembelajaran PBL-STEM sangat besar.

Hal ini dapat diartikan bahwa antara kelompok $A_{1} B_{1}$ dan $A_{1} B_{2}$ berbeda secara signifikan. Atau menunjukkan $\mathrm{H}_{1}$ diterima dan $\mathrm{H}_{0}$ ditolak dengan kata lain terdapat perbedaan kemampuan berpikir kritis kimia siswa berkemandirian tinggi dengan siswa berkemandirian rendah, pada kelompok siswa yang diajar dengan model pembelajaran PBL-STEM.

4) Kelompok $\mathrm{A}_{2} \mathrm{~B}_{1}$ dan $\mathrm{A}_{2} \mathrm{~B}_{2}$

Dari tabel hasil ANOVA uji lanjut dengan uji Tukey (Multiple Comparisons) dapat dilihat Mean Difference pada kelompok $\mathrm{A}_{2} \mathrm{~B}_{1}$ dan $\mathrm{A}_{2} \mathrm{~B}_{2}$ adalah 0.206 berarti selisih antara kelompok $\mathrm{A}_{2} \mathrm{~B}_{1}$ dan $\mathrm{A}_{2} \mathrm{~B}_{2}$ sebesar 0.206. Nilai ini cukup kecil dan dapat dibuktikan deangan signifikansi untuk $\alpha=0.05$ adalah sebesar $0.994(0.994>0.05)$.

Pada gambar 2 tampak kemiringan garis model pembelajaran konvensional sangat kecil dibandingkan dengan kemiringan garis model pembelajaran PBL-STEM.

Hal ini dapat diartikan bahwa antara kelompok $\mathrm{A}_{2} \mathrm{~B}_{1}$ dan $\mathrm{A}_{2} \mathrm{~B}_{2}$ berbeda secara signifikan. Atau menunjukkan $\mathrm{H}_{0}$ diterima dan $\mathrm{H}_{1}$ ditolak dengan kata lain tidak ada perbedaan kemampuan berpikir kritis kimia siswa berkemandirian tinggi dengan siswa berkemandirian rendah, pada kelompok siswa yang diajar dengan model pembelajaran konvensional. 


\section{Pembahasan}

Hasil pengujian hipotesis penelitian tersebut di atas ditafsirkan lebih lanjut:

\section{a. Pembahasan Hipotesis Pertama}

Berdasarkan hasil ANOVA dua arah dengan menggunakan SPSS 20 for Windows diperoleh nilai sig. $(0.000<0.005)$, dengn demikian dapat disimpulkan terdapat pengaruh yang signifikan model pembelajaran terhadap kemampuan berpikir kritis kimia. Hal ini didukung oleh perolehan rerata nilai kemampuan berpikir kritis kimia dengan model pembelajaran PBLSTEM sebesar 7.162, nilai yang lebih tinggi dari kemampuan berpikir kritis kimia dengan model pembelajaran kovensional yaitu 4.015. Hal ini menunjukkan bahwa kemampuan berpikir kritis kimia akan meningkat bila siswa diajarkan dengan model pembelajaran PBL-STEM. Penggunaan model pembelajaran tersebut dapat meningkatkan kemampuan berpikir kritis kimia sesuai yang dijelaskan oleh Barrows dan Kelson (Riyanto, 2010: 285) bahwa PBL merupakan model pembelajaran yang menuntut siswa memecahkan masalah, belajar secara mandiri, berpikir kritis dan menuntut keterampilan berpratisipasi dalam kelompok, apalagi PBL diintegrasi dengan pendekatan STEM yang mampu membangun daya berpikir dan penangalaman siswa sehingga membantu siswa SMK dalam menyiapkan keterampilannya menuju dunia kerja.

\section{b. Pembahasan Hipotesis Kedua}

Berdasarkan hasil ANOVA dua arah dengan menggunakan SPSS 20 for Windows diperoleh nilai sig. $(0.001<0.005)$, dengan demikian dapat disimpulkan terdapat pengaruh yang signifikan kemandirian belajar terhadap kemampuan berpikir kritis kimia, didukung juga dengan nilai rerata perolehan kemampuan berpikir kritis kimia siswa berkemandirian belajar tinggi sebesar 4.118, yang nilainya lebih tinggi dari kemampuan berpikir kritis kimia dengan kemandirian belajar rendah sebesar 3.912. Hal ini dapat terjadi dimungkinkan karena siswa yang memiliki kemandirian belajar tinggi memiliki semangat dalam belajar, mampu memotivasi diri, mampu belajar amndiri serta tidak mudah menyerah jika menemukan masalah. Sesuai dikatakan oleh Bandura (Uno, 2008:217) mendefinisikan, kemandirian sebagai kemampuan untuk mengontrol prilaku mereka sendiri dan juga bekerja keras, terutama seorang pelajar dalam mengontrol proses pembelajarannya.

Selain itu kemandirian belajar merupakan sikap yang datang dari dalam diri siswa akibat dari proses belajar yang telah dijalaninya. Kemandirian belajar yang tinggi akan membawa perubahan positif dalam kegiatan belajar siswa. Sementara kemandirian belajar rendah cenderung menghambat dalam proses belajar siswa.

\section{c. Pembahasan Hipotesis Ketiga}

Berdasarkan hasil ANOVA dua arah dengan menggunakan SPSS 20 for Windows diperoleh nilai sig. $(0.003<0.005)$, untuk interaktif antara model pembelajaran dan kemandirian belajar, dapat disimpulkan bahwa terdapat pengaruh interaktif yang signifikan model pembelajaran dan kemandirian belajar terhadap kemampuan berpikir kritis kimia, sehingga dilakukan uji lanjut.

Dari uji lanjut diperoleh hasil bahwa pada kelompok siswa berkemandirian belajar tinggi, terdapat perbedaan kemampuan berpikir kritis kimia pada kelompok siswa yang diajarkan dengan model pembelajaran PBL-STEM dan siswa yang diajarkan dengan model pembelajaran konvensional. Selisih antara kedua kelompok tersebut adalah 4.853, maka dapat disimpulkan bahwa pada kelompok yang siswa yang memiliki kemandirian tinggi dengan model pembelajaran PBL-STEM menghasilkan nilai kemampuan berpikir kritis kimia yang berbeda dengan model pembelajaran konvensional, karena menggunakan model pembelajaran PBL-STEM lebih efektif pembelajaran kimianya dibandingkan dengan model pembelajaran konvensional sehingga menghasilkan nilai kemampuan berpikir kritis yang lebih tinggi.

Uji lanjut pada kelompok berikutnya menunjukkan hasil bahwa pada kelompok siswa berkemandirian rendah tidak ada perbedaan kemampuan berpikir kritis kimia yang diajarkan antara model pembelajaran kelas eksperimen dengan kelass kontrol. Selisih rerata antara kelompok $\mathrm{A}_{1} \mathrm{~B}_{2}$ dan $\mathrm{A}_{2} \mathrm{~B}_{2}$ hanya 1.441, maka dapat disimpulkan bahwa pada kelompok siswa 
yang memiliki kemandirian belajar rendah, jika diajarkan dengan model pembelajaran PBLSTEM menghasilkan nilai kemampuan berpikir kritis yang hampir sama dengan nilai yang diajarkan dengan model pembelajaran konvensional, serta juga dibuktikan dengan sig. 0.272 $(0.272>0.05)$.

Kemudian hasil uji lanjut kelompok berikutnya yang lain juga diperoleh, kelompok siswa yang diajar dengan model pembelajaran PBL-STEM terdapat perbedaan kemampuan berpikir kritis antara siswa berkemandirian belajar tinggi dengan siswa berkemandirian rendah. Sedangkan, jika melihat selisih rataan kelompok $\mathrm{A}_{1} \mathrm{~B}_{1}$ dan $\mathrm{A}_{2} \mathrm{~B}_{2}$ yaitu 3.618 maka dapat disimpulkan bahwa pada kelompok siswa yang diajarkan model pembelajaran PBL-STEM, dengan kemandirian belajar tinggi menjadikan kemampuan berpikir kimia siswa yang lebih baik dari pada yang memiliki kemandirian belajar rendah.

Pengujian dengan uji Tukey yang terakhir, juga diperoleh bahwa pada kelompok siswa yang diajarkan dengan pembelajaran konvensional tidak ada perbedaan nilai kemampuan berpikir kritis kimia siswa berkemandirian tinggi dengan siswa berkemandirian rendah. Selisih rataan kedua kelompok ini $\left(\mathrm{A}_{2} \mathrm{~B}_{1}\right.$ dan $\left.\mathrm{A}_{2} \mathrm{~B}_{2}\right)$ hanya 0.206 dan juga sig. lebih besar dari 0.05 . Hal ini berkesimpulan nilai kemampuan berpikir kritis dengan menggunakan model konvensional memiliki nilai hampir sama untuk siswa berkemandirian tinggi dan rendah.

Berdasarkan hasil uji lanjut di atas maka dapat ditarik kesimpulan pada kelompok siswa yang diajarkan model pembelajaran PBL-STEM jauh lebih efektif dan lebih baik dari pada siswa dengan model pembelajaran konvensional, apalagi disertai dengan siswa yang memiliki kemandirian tinggi, dari pada siswa yang berkemandirian rendah.

\section{KESIMPULAN}

Pada bagian kesimpulan ini, peneliti menguraikan secara singkat hasil penelitian yang diperoleh sebagai berikut:

1. Terdapat pengaruh yang signifikan model pembelajaran terhadap kemampuan berpikir kritis kimia siswa SMK Negeri di Kabupaten Bogor. Hal ini dibuktikan dengan sig. = $0.000<0.005$ dan $F_{\text {hitung }}=31.693$.

2. Terdapat pengaruh yang signifikan kemandirian belajar terhadap kemampuan berpikir kritis kimia siswa SMK Negeri di Kabupaten Bogor. Hal ini dibuktikan dengan sig. = $0.001<0.005$ dan $F_{\text {hitung }}=11.696$.

3. Terdapat pengaruh interaktif yang signifikan model pembelajaran dan kemandirian belajar terhadap kemampuan berpikir kritis kimia siswa SMK Negeri di Kabupaten Bogor. Hal ini dibuktikan dengan sig. $=0.003<0.005$ dan $F_{\text {hitung }}=9.312$.

Pengaruh interaktif model pembelajaran dan kemandirian belajar terhadap kemampuan berpikir kritis kimia yang didapatkan dari hasil penelitian ini adalah sebagai berikut:

a. Terdapat perbedaan kemampuan berpikir kritis kimia yang diajarkan dengan model pembelajaran PBL-STEM dan konvensional, pada siswa berkemandirian tinggi. Hal tersebut dibuktikan dengan signifikansi untuk $\alpha=0.05$ adalah sebesar $0.000(0.000<$ $0.05)$.

b. Tidak ada perbedaan kemampuan berpikir kritis kimia yang diajarkan dengan model pembelajaran PBL-STEM dan konvensional, pada siswa berkemandirian rendah. Hal tersebut dibuktikan dengan signifikansi untuk $\alpha=0.05$ adalah sebesar $0.272(0.272>$ $0.05)$.

c. Terdapat perbedaan kemampuan berpikir kritis kimia siswa berkemandirian tinggi dengan siswa berkemandirian rendah, pada kelompok siswa yang diajar dengan model pembelajaran PBL-STEM. Hal tersebut dibuktikan dengan signifikansi untuk $\alpha=0.05$ adalah sebesar $0.000 .(0.000<0.05)$.

d. Tidak ada perbedaan kemampuan berpikir kritis kimia siswa berkemandirian tinggi dengan siswa berkemandirian rendah, pada kelompok siswa yang diajar dengan model pembelajaran konvensional. Hal tersebut dibuktikan dengan signifikansi untuk $\alpha=0.05$ adalah sebesar 0.994 (0.994 > 0.05). 


\section{DAFTAR PUSTAKA}

Cottrell, S. (2017). Critical Thinking Skills: Developing Effective, Argument and Analysis Ed. 2. United Kingdom: Macmillan Publishers Limited.

Fahmawati, S., dkk. (2015). Desain Laboratorium Skala Mini untuk Pembelajaran Sains Terpadu. Ed. 1. Yogyakarta: Deepublish.

Fatimah, E. (2010). Psikologi Perkembangan Peserta Didik. Jakarta: Pustaka Setia

Fisher, A. (2011). Critical Thinking. An Introduction. Ed. 2. United Kingdom: Cambridge University Press.

Hamalik, O. (1999). Kurikulum dan Pembelajaran. Jakarta: Bumi Aksara

Komalasari, K. (2010). Pembelajaran Konstektual, Konsep dan Aplikasi. Cet. IV. Bandung: PT. Refika Aditama

Lefudin (2017). Belajar dan Pembelajaran. Dilengkapi dengan model pembelajaran, strategi pembelajaran, pendekatan pembelajaran dan metode pembelajaran. Cet. 2. Yogyakarta: Deepublish.

Permanasari, A. (2016). STEM Education: Inovasi dalam Pembelajaran Sains. Proseding Seminar Nasional Pendidikan Sains (SNPS). Bandung: UPI.

Riyanto, Y. (2010). Paradigma Pembelajaran sebagai Referensi bagi Pendidik dalam Implementasi Pembelajaran yang Efektif dan Berkualitas. Jakarta: Prenadamedia Group.

Rusman (2018). Model-Model Pembelajaran Mengembangkan Profesionalisme Guru. Jakarta: Rajawali Pers

Sanders, M. (2009). STEM, STEM Education, STEMmania. Virginia: The Technology Teacher.

Supardi U.S. (2016). Aplikasi Statistika Dalam Penelitian. Cet. ke VI. Jakarta: PT Ufuk Publishing House.

Tan, T. (2017). Teaching is an Art: Maximize Your Teaching. Yogyakarta: Deepublish.

Tirtarahardja, U. dan La Sulo, S. L. (2005). Pengantar Pendidikan. Jakarta: PT. Rineka Cipta. Uno, H. B. (2008). Orientasi Baru Dalam Psikologi Pembelajaran. Jakarta: PT Bumi Aksara. 